\title{
UV Radiation Induced Cross-Linking of Whey Protein Isolate-Based Films
}

\author{
Markus Schmid, ${ }^{1,2}$ Tobias Konrad Prinz, ${ }^{1}$ Kerstin Müller, ${ }^{1}$ and Andreas Haas ${ }^{1}$ \\ ${ }^{1}$ Fraunhofer Institute for Process Engineering and Packaging IVV, Giggenhauser Strasse 35, 85354 Freising, Germany \\ ${ }^{2}$ Chair for Food Packaging Technology, Technische Universität München, Weihenstephaner Steig 22, 85354 Freising, Germany \\ Correspondence should be addressed to Markus Schmid; markus.schmid@ivv.fraunhofer.de
}

Received 11 April 2017; Accepted 9 May 2017; Published 4 June 2017

Academic Editor: Raffaele Cucciniello

Copyright (C) 2017 Markus Schmid et al. This is an open access article distributed under the Creative Commons Attribution License, which permits unrestricted use, distribution, and reproduction in any medium, provided the original work is properly cited.

Casted whey protein films exposed to ultraviolet irradiation were analyzed for their cross-linking properties and mechanical and barrier performance. Expected mechanical and barrier improvements are discussed with regard to quantification of the crosslinking in the UV-treated whey protein films. Swelling tests were used to determine the degree of swelling, degree of cross-linking, and cross-linking density. When the UV radiation dosage was raised, a significant increase of the tensile strength as well as an increase in Young's modulus was observed. No significant changes in water vapor and oxygen barrier properties between the UV-treated films and an untreated reference sample could be observed. The cross-linking density and the degree of cross-linking significantly increased due to UV radiation. Combined results indicate a disordered protein network in cast films showing locally free volume and therefore only minor mechanical and barrier improvements.

\section{Introduction}

Packaging materials are designed to enable long shelf life and maintain the quality of packaged products [1]. Due to the growing awareness of the consumers and the industry, the development of biopolymers increased in recent years. Those also include biodegradable packaging materials from renewable raw materials such as wheat gluten, soy protein, casein, or whey proteins [2]. Whey protein isolate- (WPI-) based films showed high barrier performance against oxygen, leading to suitable biomaterials for packaging applications [3]. WPI consists of different whey proteins, linked by thermal, chemical, biochemical, and/or physical treatments [4], such as ultraviolet (UV) irradiation. Double bonds, including aromatic rings of amino acids like tyrosine or phenylalanine, can absorb UV radiation, followed by the formation of free radicals and intermolecular covalent bonds $[5,6]$. Films derived from soy protein, corn zein, wheat gluten, peanut protein, fish gelatin, egg albumin, sodium caseinate, and whey protein have been treated with UV radiation [5-12], mainly stating various changes in final film properties. However, there is very little information on the structural changes such as UV-light-induced cross-linking mechanisms in protein films. Therefore, the objective of this work was to evaluate cross-linking properties of whey protein-based cast films depending on applied UV radiation doses. Furthermore, this study offers a direct approach for the quantification of cross-linking in protein films. Besides the determined cross-linking parameters, structure dependent properties such as mechanical and barrier performance were analyzed and discussed.

\section{Materials and Methods}

2.1. Cast Films. A glycerol plasticized denatured whey protein standard solution (WPSS) containing 10\% (w/w) WPI was prepared according to the procedure developed by Schmid et al. [3]. Films were casted into Petri dishes with a target thickness of $50 \mu \mathrm{m}$ (final thicknesses were $39 \pm 16.1 \mu \mathrm{m}$ ) and dried at ambient conditions in a climate chamber at $23^{\circ} \mathrm{C}$ and $50 \% \mathrm{RH}$ until equilibrium was proved by constant weight.

2.2. Thickness Measurement. For density calculation, mechanical and barrier tests and thickness measurements were performed with a precision thickness gauge FT3 (Rhopoint 
TABLE 1: List of the processed samples with indicated dose of UV-C (per side) and exposure time (per side).

\begin{tabular}{lcc}
\hline Sample name & $\begin{array}{c}\text { Dose of UV-C } \\
\text { (per side) }\left[\mathrm{J} / \mathrm{cm}^{2}\right]\end{array}$ & $\begin{array}{c}\text { Radiation time } \\
\text { (per side) }[\mathrm{min}]\end{array}$ \\
\hline UV_0 & 0 & 0 \\
UV_5 & $1,2 \pm 0,3$ & 5 \\
UV_10 & $2,8 \pm 0,2$ & 10 \\
UV_50 & $11,6 \pm 0,3$ & 50 \\
UV_100 & $19,9 \pm 0,1$ & 100 \\
UV_200 & $42 \pm 3,3$ & 200 \\
\hline
\end{tabular}

Instruments, Bexhill-on-Sea, UK) using average values of five random positions around the film testing area of each specimen.

2.3. Ultraviolet Radiation Treatment. For UV radiation treatment, casted films were placed under a UV cartridge (Heraeus Noblelight $\mathrm{GmbH}$, Hanau, Germany). The distance between the sample and the UV source was set to $70 \mathrm{~mm}$. The experimental setup of the ultraviolet radiation was installed in a metal housing to protect the operator from the radiation following the configuration by Schmid et al. [12].

Films were radiated on both sides. In order to stabilize the intensity of the ultraviolet radiation, the lamp was switched on at least five minutes before the samples were inserted. The UV dose determined with a UV Power Puck (Electronic Instrumentation and Technology Inc., Sterling, USA) and the applied radiation times are listed in Table 1. According to own measurements, the $\mathrm{UV}-\mathrm{C}$ radiation intensity at the center of the housing was $0.05 \pm 0.01\left[\mathrm{~W} / \mathrm{cm}^{2}\right]$. In addition, a temperature increase of up to $50^{\circ} \mathrm{C}$ was determined. The measurement was accomplished with an iButton (Maxim Integrated, San Jose, USA). After the radiation process, the films were stored at $23^{\circ} \mathrm{C}$ and $50 \% \mathrm{RH}$ prior to further characterization.

2.4. Determination of the Degree of Swelling, Degree of CrossLinking, and the Cross-Linking Density. To determine the degree of swelling (DoS), the degree of cross-linking (DoC), and the cross-linking density (CLD), swelling tests were performed according to the methods described by Schmid et al. [13] according to the DIN EN ISO 175:2000. The casted and dried films were cut to $50 \mathrm{~mm} \times 50 \mathrm{~mm}$ and weighed. After the addition of $288 \mathrm{~mL}$ of distilled water $\left(23^{\circ} \mathrm{C}\right)$, the samples were stored for 24 hours at $23^{\circ} \mathrm{C}$ and $50 \% \mathrm{RH}$. Adherent liquid was removed and films were dried at $65^{\circ} \mathrm{C}$ and high air circulation until constant weight. The DoS [\%] was then calculated as follows [13]:

$$
\mathrm{DoS}=\frac{m_{2}-m_{3}}{m_{3}} \cdot 100
$$

where $m_{2}$ is the film mass after the swelling process [g] and $m_{3}$ is the film mass after the complete drying process [g]. CLD and DoC were determined using water vapor sorption isotherms measured with a SPS sorption test system SPS-1 $\mu$
High Load (ProUmid GmbH, Ulm, Germany) at a temperature of $23^{\circ} \mathrm{C}$ with ascending and descending humidities from 0 to $90 \% \mathrm{RH}$ and 90 to $0 \% \mathrm{RH}$, respectively, using steps of $10 \%$ $\mathrm{RH}$. The DoC [\%] was calculated using the following formula [13]:

$$
\mathrm{DoC}=\frac{\overline{M_{0}}}{M_{\mathrm{C}}},
$$

where $\overline{M_{0}}[\mathrm{~g} / \mathrm{mol}]$ is the molecular weight of the average amino acids in WPI and $M_{C}[\mathrm{~g} / \mathrm{mol}]$ is the average molecular weight of the polymer between the cross-links. The applied $\overline{M_{0}}$ was 123.3 [g/mol] [13]. The CLD is defined as

$$
\mathrm{CLD}=\frac{1}{M_{\mathrm{C}}}
$$

where $M_{C}$ is the average molecular weight of the polymer between the cross-links $[\mathrm{g} / \mathrm{mol}]$.

$M_{C}$ is determined with the help of swelling experiments and calculated with the equation of Flory-Rehner [14-16]:

$$
M_{c}=-\frac{\rho_{\mathrm{WPI}} \cdot V_{2} \cdot\left(\varphi_{1}{ }^{1 / 3}-\varphi_{1} / 2\right)}{\ln \left(1-\varphi_{1}\right)+\varphi_{1}+\chi \cdot \varphi_{1}{ }^{2}}
$$

where $V_{2}\left[\mathrm{~cm}^{3} * \mathrm{~mol}^{-1}\right]$ is the molar volume of the deionized

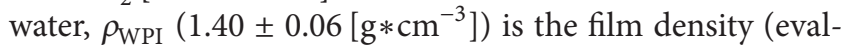
uated following [17]), $\varphi_{1}[-]$ is the volume fraction of the polymer in the swollen gel, and $\chi$ is the interaction parameter of the water and the WPI.

The volume fraction of the polymer in the swollen gel $\varphi_{1}$ is defined as

$$
\varphi_{1}=\frac{m_{\mathrm{WPI}} / \rho_{\mathrm{WPI}}}{m_{\mathrm{WPI}} / \rho_{\mathrm{WPI}}+m_{s} / \rho_{s}},
$$

where $m_{\mathrm{WPI}}[\mathrm{g}]$ is the polymer mass in the swollen gel, $\rho_{\text {WPI }}\left[\mathrm{g} * \mathrm{~cm}^{-3}\right]$ is the film density, $m_{s}[\mathrm{~g}]$ is the mass of water in the swollen gel, and $\rho_{s}\left[\mathrm{~g} * \mathrm{~cm}^{-3}\right]$ is the water density.

The Flory-Huggins equation was fitted with the least squares method to the determined water vapor sorption isotherms with the help of the Excel solver tool (Microsoft Office Professional Plus 2010, Version 14.0.7177.5000). This is essential to determine the interaction parameter $\chi$. The FloryHuggins equation $[18,19]$ is

$$
\frac{\Delta \mu^{\text {mix }}}{R T}=\ln a_{w}=\ln \left(1-\varphi_{1}\right)+\varphi_{1}+\chi \cdot \varphi_{1}{ }^{2},
$$

where $\Delta \mu^{\mathrm{mix}}\left[\mathrm{J} * \mathrm{~mol}^{-1} * \mathrm{~K}^{-1}\right]$ is the chemical potential difference of the WPI film and water, $R$ is the ideal gas constant $\left[\mathrm{J} * \mathrm{~mol}^{-1} * \mathrm{~K}^{-1}\right], T$ is the temperature $[\mathrm{K}], \varphi_{1}[-]$ is the volume fraction of the polymer in the swollen gel, and $\chi[-]$ is the interaction parameter.

2.5. Determination of Mechanical Properties. Tensile strength, elongation at break, and Young's modulus were determined using a tensile testing machine Z005 (Zwick GmbH \& Co. KG, Ulm, Germany) according to DIN EN ISO 527-1. 
For the measurement, ten sample strips of $15 \mathrm{~mm}$ width were cut out of the films and clamped into the testing machine at $23^{\circ} \mathrm{C}$ and $50 \% \mathrm{RH}$. The clamping length was set to $50 \mathrm{~mm}$ and the applied force was $50 \mathrm{~N}$ until breakage with a testing speed of $100 \mathrm{~mm} / \mathrm{min}$. Young's modulus was measured with a testing speed of $0.5 \mathrm{~mm} / \mathrm{min}$.

2.6. Determination of Barrier Properties. Water vapor transmission rate (WVTR) was measured at $23^{\circ} \mathrm{C}$ and a decreasing relative humidity from $50 \%$ to $0 \%$ with a gravimetric method according to DIN 53122-1 with a fourfold determination [20]. Specimens were weighed four times in 48 hours when constant weight was reached. The water vapor transmission rate was calculated with

$$
\mathrm{WVP}=\frac{\mathrm{WVTR}}{\Delta p\left(\mathrm{H}_{2} \mathrm{O}\right)} * d,
$$

where WVP is the water vapor permeation coefficient $\left[\mathrm{g} \mu \mathrm{m} \mathrm{m}^{-2} \mathrm{~d}^{-1}\right.$ bar $\left.^{-1}\right]$, WVTR is the water vapor transmission rate $\left[\mathrm{g} \mathrm{m}^{-2} \mathrm{~d}^{-1}\right], \Delta p\left(\mathrm{H}_{2} \mathrm{O}\right)$ is the partial pressure difference between the two chambers [bar], and $d$ is the thickness of the film $[\mu \mathrm{m}]$.

Oxygen permeability (OP) was measured at $23^{\circ} \mathrm{C}$ and 50\% RH according to DIN 53380-3 with an OX-Tran Twin Oxygen Permeation Measuring Machine (MOCON Inc. World Headquarters, Minneapolis, USA). An oxygen permeation coefficient (OP) $\left[\mathrm{cm}^{3} \mathrm{~m}^{-2} \mathrm{~d}^{-1}\right.$ bar $\left.^{-1}\right]$ was applied which is defined as the oxygen transmission rate (OTR) in relation to the partial pressure $\Delta p\left(\mathrm{O}_{2}\right)$ [bar] between both sides of the film, multiplied by its thickness $d$ [ $\mu \mathrm{m}][20]$ :

$$
\mathrm{OP}=\frac{\mathrm{OTR}}{\Delta p\left(\mathrm{O}_{2}\right)} * d
$$

2.7. Statistical Evaluation. All statistical tests were performed with the software Visual-XSel ${ }^{\circledR}$ Version 12.1 (CRGRAPH GbR, Starnberg, Germany). Except for oxygen permeability measurements (twofold determination), all sample sets were checked on normal distribution. According to the number of repeated measurements, different normality tests were applied which were the Kolmogorov-Smirnov test (sample size $\leq 4$ ) or the Anderson-Darling normality test (sample size $\geq 5$ ). The tests were performed with a significance value $(\alpha)$ of 0.05 [21]. For sample comparison, a multi- $t$-test was performed with a significance value of 0.05 . Significant differences between samples detected with the multi-t-test are marked by different letters within figures and tables.

\section{Results and Discussion}

\subsection{Intermolecular Characteristics}

3.1.1. Cross-Linking Density and Degree of Cross-Linking. Figure 1 shows CLD and DoC values depending on the applied UV dose as well as a nonradiated reference.

Except for samples with a radiation time of 5 and $50 \mathrm{~min}$, radiated samples showed significantly higher CLD and DoC

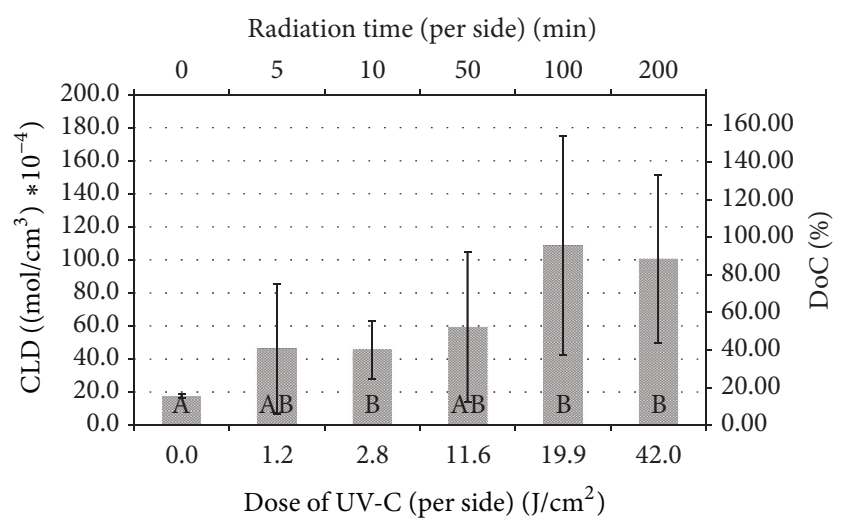

FIGURE 1: Influence of UV radiation dose and respective radiation time on DoC and CLD of WPI-based cast films. Bars with different letters are significantly different $(p<0.05)$.

values compared to the reference sample. Due to high standard deviations, the other samples do not differ significantly among each other. High deviations probably resulted from difficult handling of the thin films. DoC and CLD increase with a rising radiation dose. The highest CLD and DoC were determined with a UV-C dose of $19.9 \mathrm{~J} / \mathrm{cm}^{2}$ with a CLD of about $110 * 10^{-4} \mathrm{~mol} / \mathrm{cm}^{3}$. Up to now, only few comparable studies are known to the authors dealing with cross-linking properties of whey protein-based cast films. However, since natural rubber is also cross-linked via disulfide bridges and shows similar mechanical behavior, results described by Ahmed et al. [22] are chosen for comparison. The CLD of natural rubber of $2.0 * 10^{-4} \mathrm{~mol} / \mathrm{cm}^{3}$ is significantly exceeded compared to the CLD of the whey protein standard formulation with $18 * 10^{-4} \mathrm{~mol} / \mathrm{cm}^{3}$. Previous studies on whey protein films determined a cross-linking density of 1.7 $* 10^{-4} \mathrm{~mol} / \mathrm{cm}^{3}$ for the standard whey protein formulation [13]. The deviation of the measured values from the literature values is caused by several influencing factors. The most influencing factor is the volume fraction of the polymer in the swollen gel, which is determined by swelling experiments. It has a particularly high influence on the average molecular weight of the polymer between the cross-links $\left(M_{C}\right)$, the degree of cross-linking, and the cross-linking density. It is stated that UV radiation significantly increases the crosslinking between the protein fractions at a radiation time of $10 \mathrm{~min}$. Schmid et al. [12] concluded that a large proportion of the cross-linkages are already linked during the first $10 \mathrm{~min}$ of radiation. It is assumed that the required energy for the formation of radicals is already present at a dose of about $3 \mathrm{~J} / \mathrm{cm}^{2}$, resulting in protein cross-linking by a chain-growing process, which was qualitatively confirmed in this study with the methods described by Schmid et al. [12].

3.1.2. Degree of Swelling. The DoS (see Figure 2) of the radiated samples behaves contrarily to the DoC and CLD. The reference sample has the highest DoS value with about $210 \%$, while DoS tends to decrease with an increasing UV$\mathrm{C}$ dose. This effect is consistent with the investigations 
TABLE 2: Mechanical properties of UV-treated WPI-based films as a function of UV dose and radiation time; significant differences are indicated by different letters $(p<0.05)$.

\begin{tabular}{|c|c|c|c|c|}
\hline $\begin{array}{l}\text { UV-C dose } \\
\text { (per side) }\left[\mathrm{J} / \mathrm{cm}^{2}\right]\end{array}$ & $\begin{array}{l}\text { Radiation time } \\
\text { (per side) [min] }\end{array}$ & $\begin{array}{c}\text { Young's modulus } \\
{[\mathrm{MPa}]}\end{array}$ & Tensile strength $[\mathrm{MPa}]$ & Elongation at break ${ }^{*}[\%]$ \\
\hline 0.0 & 0 & $69.8 \pm 52.4^{\mathrm{ab}}$ & $4.52 \pm 0.75^{\mathrm{a}}$ & $23.7 \pm 20.1^{\mathrm{ab}}$ \\
\hline 1.2 & 5 & $65.1 \pm 15.7^{\mathrm{a}}$ & $4.32 \pm 0.25^{\mathrm{a}}$ & $43.2 \pm 19.7^{\mathrm{a}}$ \\
\hline 2.8 & 10 & $65.7 \pm 31.7^{\mathrm{a}}$ & $6.38 \pm 0.57^{\mathrm{b}}$ & $42.6 \pm 30.6^{\mathrm{ab}}$ \\
\hline 11.6 & 50 & $114.5 \pm 44.3^{\mathrm{ab}}$ & $7.39 \pm 0.67^{\mathrm{c}}$ & $25.5 \pm 7.0^{\mathrm{ab}}$ \\
\hline 19.9 & 100 & $112.8 \pm 22.5^{\mathrm{b}}$ & $7.58 \pm 0.51^{\mathrm{c}}$ & $30.7 \pm 12.1^{\mathrm{a}}$ \\
\hline 42.0 & 200 & $227.7 \pm 149.5^{\mathrm{ab}}$ & $13.61 \pm 3.64^{\mathrm{d}}$ & $14.1 \pm 9.1^{\mathrm{b}}$ \\
\hline
\end{tabular}

${ }^{*}$ Layer thicknesses in $\mu \mathrm{m}$ according to the increasing radiation time: $47.0 \pm 8.2,49.2 \pm 9.3,48.4 \pm 8.0,38.0 \pm 5.7,49.3 \pm 9.9$, and $37.5 \pm 7.9$.

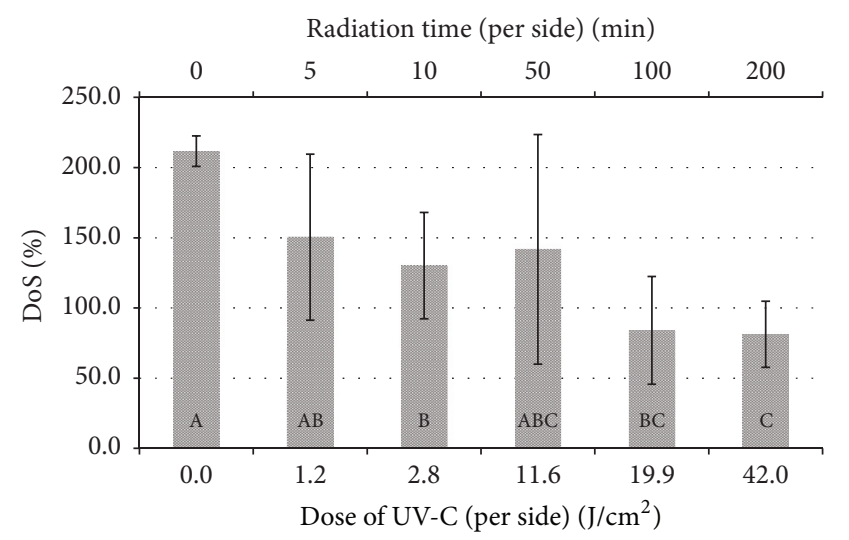

FIGURE 2: Degree of swelling as a function of the UV dose and the radiation time; bars with different letters are significantly different $(p<0.05)$.

of Schmidt et al. [23], who stated that an increasing proportion of cross-links within the polymer structure leads to a decreasing swelling capability. The behavior is attributed to the decreasing free volume with an increasing cross-linking density in the polymer network. Comparing the determined DoS of the WPI films with those of natural rubber (of about $370 \%$ according to Ahmed et al. [22]), the DoS of the standard whey protein formulation were reduced by half. The radiated samples have lower values, especially at a radiation time of 200 min with a degree of swelling of about $80 \%$, indicating cross-linking reactions. It should be noted that, compared to the reference, the DoS of the film which was treated with a radiation time of $10 \mathrm{~min}$ is significantly lower.

3.2. Mechanical Properties. Mechanical data of all samples can be seen in Table 2. Young's modulus of the prepared films shows almost no significant differences between the samples, except for the sample with a radiation time of $100 \mathrm{~min}$, at which Young's modulus is significantly higher than Young's modulus of the samples with radiation times of 5 or $10 \mathrm{~min}$. Due to high standard deviations, only few statistical differences could be detected. However, a general increase of the mean Young's moduli with an increased UVC dose can be observed. Ustunol and Mert [24] stated that UV radiation of the film-forming solution has no significant effect on Young's modulus. Young's modulus of the UV-treated cast films has been studied by Schmid et al. [12], who can partly confirm this effect. This means that a significant increase could be observed when measuring in the cross direction, but not in machine direction. During the coating process, protein molecules are oriented in machine direction. Therefore, cross-links between the protein chains rather occur in cross direction. An explanation of the polymer orientation effect is described in Figure 3.

Figure 3 shows that, in the extreme case, the cast film can only form cross-links between the ends of the polymer chains. The forming of cross-links along the polymer chains results in a high Young's modulus. Polymer orientation does not occur in cast films, but a disordered network is present. This is the reason why the film can be stressed equally in all directions. The polymer chains interfere with each other, resulting in a big distance between them. Then, the proteins are not able to form cross-links anymore and the free volume of the films increases. In addition, the films are about twice as thick as the coatings described by Schmid et al. [12]. The films were radiated on both sides to compensate for the higher layer thickness. Díaz et al. [7] radiated non-heat-treated whey protein concentrate cast films with a significantly higher layer thickness of $120-145 \mu \mathrm{m}$ on only one film side with doses of up to $12 \mathrm{~J} / \mathrm{cm}^{2}$, without any significant effect on Young's modulus. This is probably caused by the low UV dose $\left(2.8 \mathrm{~J} / \mathrm{cm}^{2} ; 25 \mu \mathrm{m} ; 0.0 \mathrm{~J} / \mathrm{cm}^{2}\right)$.

The tensile strength of the UV cross-linked films increased significantly with an increasing radiation time and dose. The tensile strength of the sample which was treated with a UV-C dose of $1.2 \mathrm{~J} / \mathrm{cm}^{2}$ did not increase compared to the reference sample. These results confirm the investigations of Schmid et al. [12] about UV-radiated coatings, who tested their peeled-off coatings in machine direction. The usage of cast films (where the protein molecules are disordered in the film) leads to cross-linking at different positions. This creates a chaotic network where the tensile strength increases with an increasing degree of cross-linking. Díaz et al. [7] also observed an increase of the tensile strength at radiated cast films.

Due to high standard deviations, elongation at break measurements showed no significant differences between the films, except for the film with 200-minute treatment. The elongation at break of this sample is significantly lower than 

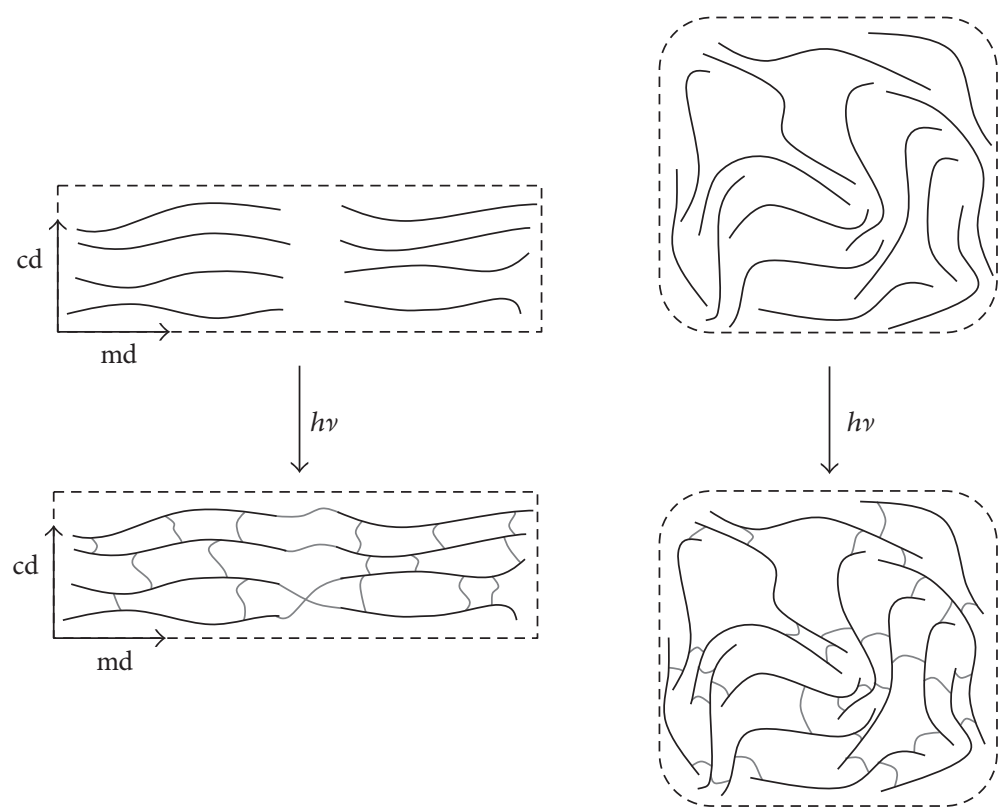

FIGURE 3: Film morphology of WPSS coatings (cd: cross direction; md: machine direction; adapted from Schmid et al. [12]) and cast films after UV radiation; the figure shows the additional covalent intermolecular interactions induced by UV radiation; disulfide bonds are not shown.

of the samples which were radiated for 5 or $100 \mathrm{~min}$. The film thicknesses are not considered during the measurement of the elongation at break. Compared to the other samples, the films (radiated for 50 or $200 \mathrm{~min}$ ) which have lower elongation at break are up to $20 \%$ thinner. These results are confirmed by Schmid et al. [12] as well as Díaz et al. [7], who showed that the UV radiation has no significant influence on the elongation at break.

3.3. Barrier Properties. Water vapor transmission rate and oxygen permeability of UV-radiated samples as well as the reference sample are shown in Table 3. There were no significant differences between the samples. No significant differences between the film samples were detectable, concluding that UV radiation has no significant effect on the water vapor transmission rate of whey protein cast films. Ustunol and Mert [24] stated the same conclusion, but they worked with a radiated film-forming solution and not with radiated dry whey protein films. Díaz et al. [7], who observed WPC cast films, did not detect any significant influence of the UV radiation on the water vapor transmission rate. This could also be explained by a disordered protein network where cross-links only occur at the end of the polymer chains (Figure 3). For the diffusion path of the water vapor molecules, these cross-links are negligible since the pathway is rather oriented at the free volume sections between the polymer chains.

The same could be applied for oxygen permeability, since results of the samples also differ minimally from each other; only the sample which was radiated for $5 \mathrm{~min}$ shows an increased OP. This would correspond to the results of Schmid et al. [12], who did not detect any significant change in the oxygen barrier by UV-radiated coatings.
TABLE 3: Water vapor transmission rate and oxygen permeability normalized to $100 \mu \mathrm{m}$ film thickness as a function of the UV dose. Different letters indicate significant differences $(p<0.05)$.

\begin{tabular}{lccc}
\hline $\begin{array}{l}\text { UV-C dose } \\
\text { (per side) } \\
{\left[\mathrm{J} / \mathrm{cm}^{2}\right]}\end{array}$ & $\begin{array}{c}\text { Radiation } \\
\text { time }(\text { per } \\
\text { side) }[\mathrm{min}]\end{array}$ & $\begin{array}{c}\text { Water vapor } \\
\text { transmission } \\
\text { rate } \mathrm{Q}_{100} \\
{\left[\mathrm{~g} /\left(\mathrm{m}^{2} \mathrm{~d}\right)\right]}\end{array}$ & $\begin{array}{c}\text { Oxygen } \\
\text { permeability }\end{array}$ \\
\hline 0.0 & 0 & $92.7 \pm 44.0^{\mathrm{a}}$ & $\begin{array}{c}\mathrm{Q}_{100} \\
{\left[\mathrm{~cm}^{3} /\left(\mathrm{m}^{2} \mathrm{~d} \text { bar }\right)\right]}\end{array}$ \\
1.2 & 5 & $48.1 \pm 11.7^{\mathrm{a}}$ & $24.3 \pm 8.5$ \\
2.8 & 10 & $48.0 \pm 17.5^{\mathrm{a}}$ & $16.5 \pm 4.1$ \\
11.6 & 50 & $59.1 \pm 22.4^{\mathrm{a}}$ & $16.0 \pm 2.1$ \\
19.9 & 100 & $61.8 \pm 18.9^{\mathrm{a}}$ & $17.0 \pm 4.9$ \\
42.0 & 200 & $44.5 \pm 8.2^{\mathrm{a}}$ & $13.9 \pm 2.0$ \\
\hline
\end{tabular}

${ }^{*}$ Twofold determination. Mean of minimum and maximum value.

\section{Conclusion}

The UV cross-linked films show a significant increase in the tensile strength from $4.52 \mathrm{MPa}$ (reference sample) to 13.61 $\mathrm{MPa}$ after $200 \mathrm{~min}$ of radiation and to $6.38 \mathrm{MPa}$ after $10 \mathrm{~min}$ of radiation. A trend increase is present in Young's modulus with an increasing radiation process. The film treatment with UV radiation did not lead to a significant change of the barrier properties. One possible reason for this occurrence is that the polymers in casting films are present in a disordered network, resulting in locally free volumes. These volumes offer a small diffusion barrier to oxygen and water molecules. The cross-linking density and degree of cross-linking increased significantly, while the degree of swelling was significantly reduced by UV radiation. The CLD increased from $17.7 * 10^{-4}\left(\mathrm{~mol} / \mathrm{cm}^{3}\right)$ of the UV reference to 
$108.9 * 10^{-4}\left(\mathrm{~mol} / \mathrm{cm}^{3}\right)$ of the sample which was treated with a UV dose of $19.9 \mathrm{~J} / \mathrm{cm}^{2}$ on both sides. All in all, the developed methods can provide cross-linking quantification and can be further used to elucidate the morphology of protein network in whey protein films.

\section{Conflicts of Interest}

The authors declare no conflicts of interest regarding the publication of this paper.

\section{Acknowledgments}

This work was supported by the German Research Foundation (DFG) and the Technische Universität München within the funding programme Open Access Publishing. The authors wish to acknowledge the support of all involved colleagues in the Materials Development and Process Engineering Departments at Fraunhofer IVV. Special thanks are extended to Zuzana Scheuerer and Marius Jesdinszki for their outstanding support.

\section{References}

[1] J. Multon, “The role of packaging in preserving foodstuffs," Food Packaging Technology, 1, 3-23, 1996.

[2] M.-B. Coltelli, F. Wild, E. Bugnicourt et al., "State of the art in the development and properties of protein-based films and coatings and their applicability to cellulose based products: an extensive review," Coatings, vol. 6, no. 1, p. 1, 2016.

[3] M. Schmid, K. Dallmann, and E. Bugnicourt, "Properties of whey-protein-coated films and laminates as novel recyclable food packaging materials with excellent barrier properties," International Journal of Polymer Science, vol. 2012, Article ID 562381, 7 pages, 2012.

[4] M. Wihodo and C. I. Moraru, "Physical and chemical methods used to enhance the structure and mechanical properties of protein films: a review," Journal of Food Engineering, vol. 114, no. 3, pp. 292-302, 2013.

[5] A. Gennadios, J. W. Rhim, A. Handa, C. L. Weller, and M. A. Hanna, "Ultraviolet radiation affects physical and molecular properties of soy protein films," Journal of Food Science, vol. 63, no. 2, pp. 225-228, 1998.

[6] J. W. Rhim, A. Gennadios, D. Fu, C. L. Weller, and M. A. Hanna, "Properties of ultraviolet irradiated protein films," LWT-Food Science and Technology, vol. 32, no. 3, pp. 129-133, 1999.

[7] O. Díaz, D. Candia, and Á. Cobos, "Effects of ultraviolet radiation on properties of films from whey protein concentrate treated before or after film formation," Food Hydrocolloids, vol. 55, pp. 189-199, 2016.

[8] C.-C. Liu, A. M. Tellez-Garay, and M. E. Castell-Perez, "Physical and mechanical properties of peanut protein films," $L W T$-Food Science and Technology, vol. 37, no. 7, pp. 731-738, 2004.

[9] V. Micard, R. Belamri, M.-H. Morel, and S. Guilbert, "Properties of chemically and physically treated wheat gluten films," Journal of Agricultural and Food Chemistry, vol. 48, no. 7, pp. 2948-2953, 2000.

[10] C. G. Otoni, R. J. Avena-Bustillos, B.-S. Chiou, C. BilbaoSainz, P. J. Bechtel, and T. H. McHugh, "Ultraviolet-B radiation induced cross-linking improves physical properties of cold- and warm-water fish gelatin gels and films," Journal of Food Science, vol. 77, no. 9, pp. E215-E223, 2012.

[11] J. W. Rhim, A. Gennadios, A. Handa, C. L. Weller, and M. A. Hanna, "Solubility, tensile, and color properties of modified soy protein isolate films," Journal of Agricultural and Food Chemistry, vol. 48, no. 10, pp. 4937-4941, 2000.

[12] M. Schmid, J. Held, F. Hammann, D. Schlemmer, and K. Noller, "Effect of UV-radiation on the packaging-related properties of whey protein isolate based films and coatings," Packaging Technology and Science, vol. 28, no. 10, pp. 883-899, 2015.

[13] M. Schmid, S. Pröls, D. M. Kainz, F. Hammann, and A. Stäbler, "Impact of hydrolyzed whey protein on the molecular interactions and cross-linking density in whey protein isolatebased films," International Journal of Polymer Science, vol. 2016, 9 pages, 2016.

[14] B. Isik and M. Kis, "Preparation and determination of swelling behavior of poly(acrylamide-co-acrylic acid) hydrogels in water," Journal of Applied Polymer Science, vol. 94, no. 4, pp. 1526-1531, 2004.

[15] E. Favre, Q. T. Nguyen, P. Schaetzel, R. Clément, and J. Néel, "Sorption of organic solvents into dense silicone membranes. Part 1.-validity and limitations of Flory-Huggins and related theories," Journal of the Chemical Society, Faraday Transactions, vol. 89, no. 24, pp. 4339-4346, 1993.

[16] J. L. Valentín, J. Carretero-González, I. Mora-Barrantes, W. Chassé, and K. Saalwächter, "Uncertainties in the determination of cross-link density by equilibrium swelling experiments in natural rubber," Macromolecules, vol. 41, no. 13, pp. 4717-4729, 2008.

[17] M. Schmid, S. Sängerlaub, L. Wege, and A. Stäbler, "Properties of transglutaminase crosslinked whey protein isolate coatings and cast films," Packaging Technology and Science, vol. 27, no. 10, pp. 799-817, 2014.

[18] P. J. Flory, “Themodynamics of high polymer solutions," The Journal of Chemical Physics, vol. 10, no. 1, pp. 51-61, 1942.

[19] M. L. Huggins, "Solutions of long chain compounds," Journal of Chemical Physics, vol. 9, no. 5, p. 440, 1941.

[20] G. F. Mehyar and J. H. Han, "Physical and mechanical properties of high-amylose rice and pea starch films as affected by relative humidity and plasticizer," Journal of Food Science, vol. 69, no. 9, pp. E449-E454, 2004.

[21] H. Holland and K. Scharnbacher, Grundlagen statistischer WahrscheinlichkeitenKombinationen, Wahrscheinlichkeiten, Binomial- und Normalverteilung, Konfidenzintervalle, Hypothesentests, Springer Gabler, Wiesbaden, Germany, 2004.

[22] K. Ahmed, S. S. Nizami, N. Z. Raza, and K. Mahmood, "Mechanical, swelling, and thermal aging properties of marble sludge-natural rubber composites," International Journal of Industrial Chemistry, vol. 3, no. 1, pp. 1-12, 2012.

[23] M. Schmidt, N. Rodler, O. Miesbauer et al., "Adhesion and barrier performance of novel barrier adhesives used in multilayered high-barrier laminates," Journal of Adhesion Science and Technology, vol. 26, no. 20-21, pp. 2405-2436, 2012.

[24] Z. Ustunol and B. Mert, "Water solubility, mechanical, barrier, and thermal properties of cross-linked whey protein isolatebased films," Journal of Food Science, vol. 69, no. 3, pp. FEP129FEP133, 2004. 

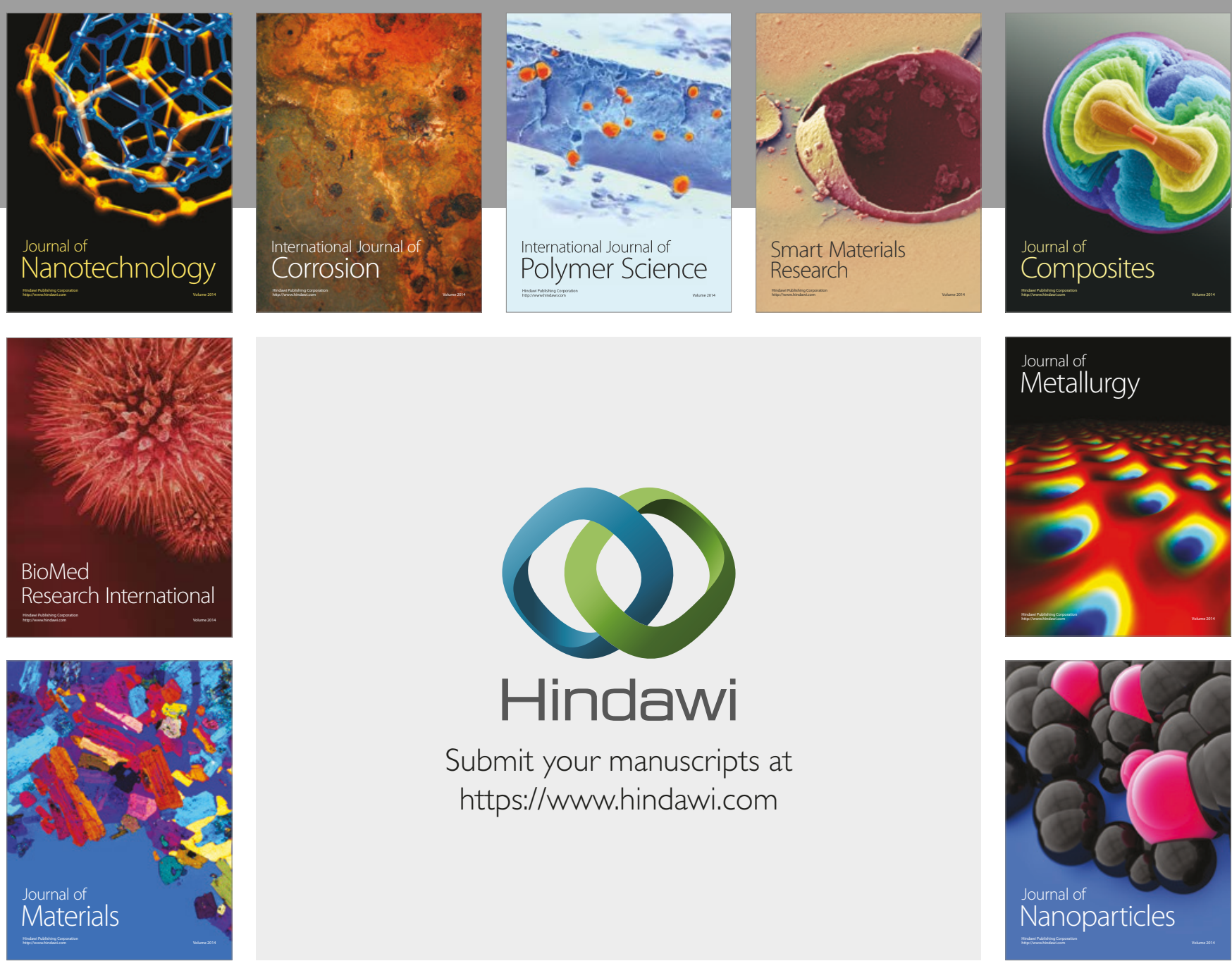

\section{Hindawi}

Submit your manuscripts at

https://www.hindawi.com
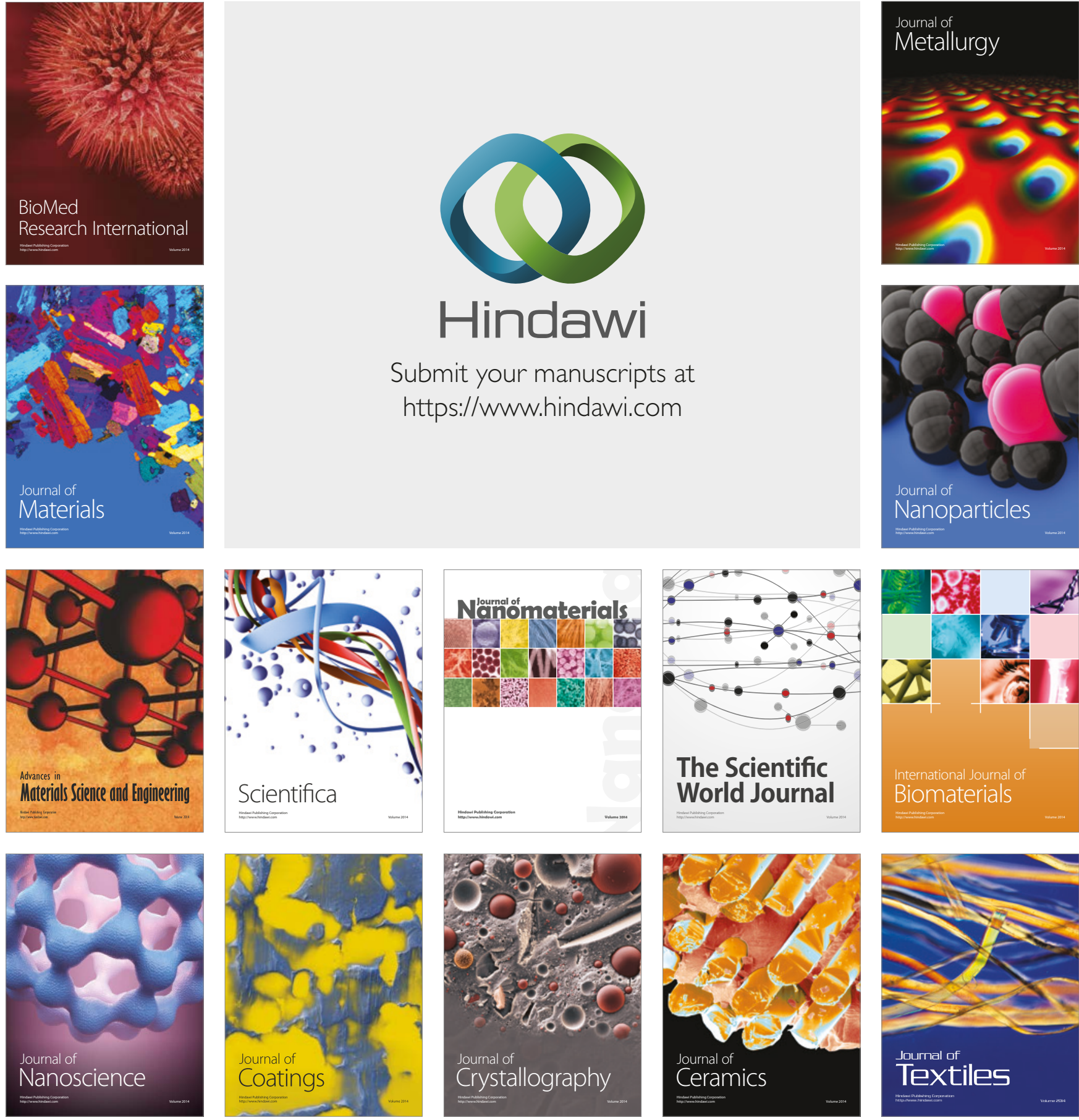

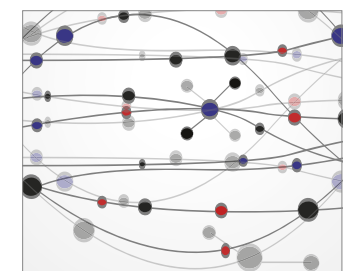

The Scientific World Journal
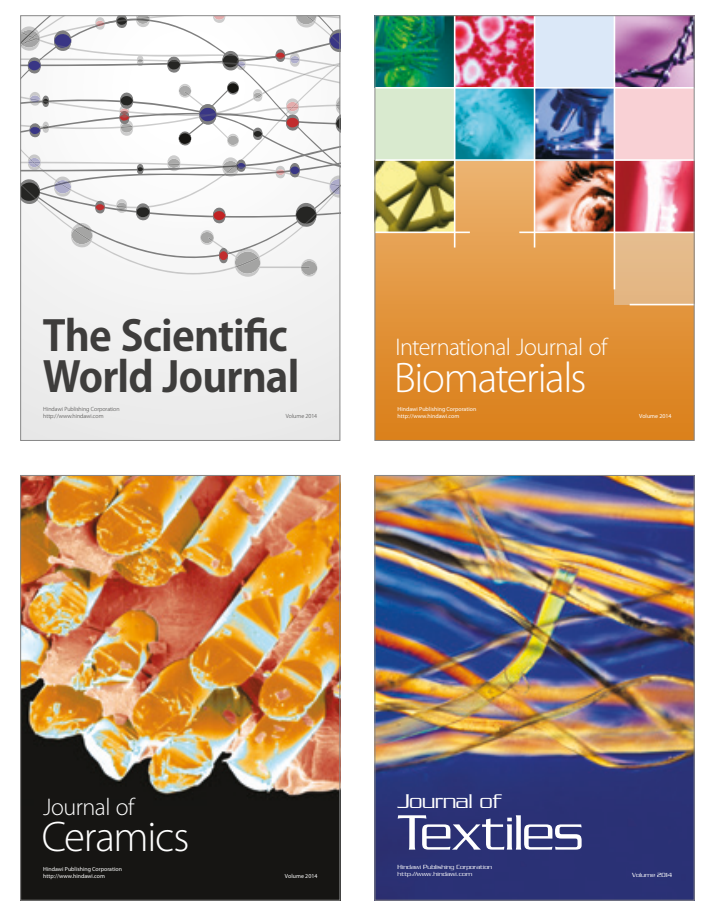